\title{
Ainda à espera dos homens do amanhã
}

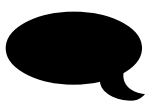

Nobu Chinen
Universidade Federal do Rio de Janeiro

Nos últimos anos, a bibliografia sobre histórias em quadrinhos publicada no Brasil vem crescendo significativamente, principalmente se comparada com o ritmo de lançamento de dez ou quinze anos atrás. Antes restritas à Comunicação ou à Linguística, as pesquisas sobre quadrinhos têm ganho terreno em outras áreas do conhecimento como a Psicologia e a História que podem trazer grandes contribuições para a compreensão dos quadrinhos ao tratar do tema com novos olhares e sob outras perspectivas metodológicas. Um ótimo exemplo é o livro Os novos homens do amanhã (2018), de Ivan Lima Gomes, doutor em História pela Universidade Federal Fluminense, que se aprofunda na análise do contexto político e social de duas iniciativas de nacionalização de quadrinhos que ocorreram no Brasil e no Chile, respectivamente, na década de 1960 e 1970: a CETPA - Cooperativa Editora e de Trabalho de Porto Alegre, e a Editoria Nacional Quimantú.

Ao apresentar em minúcias a produção e os bastidores da CETPA, a excelente pesquisa de Ivan Lima Gomes - cuja versão em monografia recebeu o prêmio HQMIX, na categoria Melhor Tese de Doutorado, de 2015 -, traz mais luz a esse episódio que, do contrário, continuaria sendo lembrado apenas como um ato de resistência, uma mera passagem folclórica. O livro, além de esclarecer apropriadamente sobre aquela experiência gaúcha, permite também conhecer um pouco mais sobre a indústria de quadrinhos, e da imprensa chilena de modo geral, durante os breves anos sob o regime socialista, no começo dos anos 1970.

Com exceção da Argentina, cujas histórias em quadrinhos mereceram um estudo bastante abrangente de Paulo
Ramos, no livro Bienvenido (2010), aqui no Brasil sabemos bem pouco sobre a produção quadrinística da América do Sul. Quase nada sobre outros vizinhos, como Paraguai, Uruguai ou Colômbia. Do Chile, com o qual não fazemos fronteira, o personagem mais conhecido é Condorito, do cartunista Pepo, que chegou a ter distribuição internacional. Curiosamente, a maior referência sobre quadrinhos vinda do Chile que tínhamos até então era o livro Para Ler o Pato Donald (1978), de Armand Mattelart e Ariel Dorfman, cuja primeira edição brasileira foi publicada em e ao imperialismo, mais especificamente, o praticado por governos e corporações norte-americanos. Durante anos, essa obra, cujos autores assumidamente editaram e deturparam os exemplos escolhidos para defender os seus propósitos, foi utilizado para acusar os quadrinhos da Disney, muito populares no Chile. O livro, inclusive, foi publicado dentro do mesmo projeto de doutrinação socialista que definiu a linha editorial da Quimantú.

É necessário lembrar que a fase escolhida por Ivan Gomes retrata justamente um momento histórico bastante crítico no continente sulamericano, marcado por golpes militares que derrubaram governos legitimamente eleitos e implantaram regimes ditatoriais alinhados com o conservadorismo dos Estados Unidos, que adotaram como prática as perseguições a seus opositores e a censura aos meios de comunicação. Os golpes militares, aliás, foram determinantes para inviabilizar e encerrar as atividades tanto da CETPA quanto da Quimantú.

Apenas a título de comparação, o desaparecimento, durante o regime militar na Argentina, de Hector Oesterheld, o 1975, editado como crítica ao capitalismo
1. Doutor em Ciências da Comunicação pelo Programa de Pós-Gradução em Ciências da Comunicação da Escola de Comunicações e Artes da Universidade de São Paulo. Membro do Observatório de Histórias em Quadrinhos da ECA-USP. Organizador das Jornadas Internacionais de Histórias em Quadrinhos. Email: nobuchinen@uol.com.br.

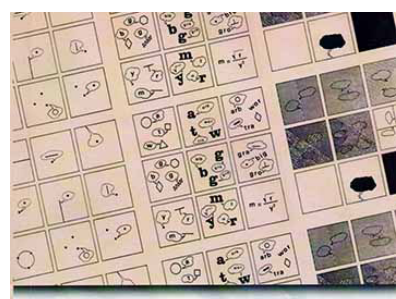

IVAN LIMA GOMES

OS NOVOS HOMENS DO AMANHÃ

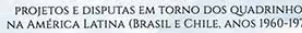

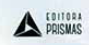

GOMES, Ivan Lima. Os novos homens do amanhã: projetos e disputa em torno dos quadrinhos na América Latina. Curitiba: Editora Prismas, 2018. 
mais consagrado roteirista de quadrinhos do país, é um episódio bem conhecido e comentado em vários livros; menos divulgado, porém, é o caso de Luis Jiménez, cartunista chileno que atuou na Quimantú e cujo desaparecimento é relatado por Jorge Montealegre, no livro Apariciones y desapariciones de Luís Jiménez (2011).

De modo geral, a CETPA é mencionada de forma muito breve em alguns livros sobre os quadrinhos brasileiros. Costuma-se citar personagens e autores, mas há poucas referências às articulações nos bastidores e nenhuma informação sobre como a cooperativa funcionava na prática. Uma exceção é o livro Guerra dos gibis (2004), de Gonçalo Júnior, diversas vezes citado por Gomes, que apresenta um panorama abrangente, mas não entra em detalhes. Nesse sentido, o livro que aborda esse episódio com mais propriedade é o Apressado para nada (2001), de José Geraldo Barreto, um relato autobiográfico de um dos mais atuantes protagonistas da CETPA, autor que também serviu de fonte para Gomes, que o entrevistou para esse trabalho. Barreto, porém, oferece uma visão pessoal dos fatos, que Gomes, após recorrer a diversas fontes e entrevistar vários dos profissionais que participaram da CETPA, pôde confrontar.

É compreensível que o autor tivesse a intenção de traçar paralelos $e$ encontrar pontos comuns entre os dois acontecimentos, afinal, aparentemente, haveria diálogos entre ambos. No entanto, é possível concluir que, fora o fato de serem focadas na produção editorial de quadrinhos, pouca coisa havia de semelhante. A CETPA se configurou mais como um projeto do que como movimento, o que a princípio se propunha ser, pois envolveu um número bem menor de profissionais, cerca de dez ao todo, e que não compartilhavam de um objetivo único. O interesse da CETPA e de outras tentativas do gênero que a antecederam, era estabelecer uma reserva de mercado para os autores nacionais por meio de lei específica e isso fica nítido ao atrelar sua organização à figura do governador Leonel Brizola. O nacionalismo das séries e títulos publicados não tinha um direcionamento ideológico à esquerda, mas visava combater o material norte-americano. $\mathrm{O}$ sistema cooperativo de produção também não chegou a ser praticado, pois os autores não participavam das decisões editoriais, limitando-se a seguir os mesmos esquemas de criação e produção convencionais.

Já o caso chileno, desde o início, integrava um projeto político de alinhamento ao governo socialista de Salvador Allende, tanto que a editora Zig-Zag foi adquirida e rebatizada de Quimantú, nome de forte conotação nacionalista e comunitária.

Os depoimentos colhidos ou selecionados por Gomes deixam entrever muito mais as razões do fracasso de ambas as iniciativas, geradas, principalmente, pela divergência entre seus componentes quanto aos rumos editoriais.

Tanto a CETPA quanto a Quimantú, tentaram, cada uma à sua maneira, propor novas publicações e personagens em substituição ao predomínio da produção norte-americana, simbolizada pelos super-heróis. Estes são referidos como homens do amanhã, em alusão a um dos qualificativos como o Super-homem é conhecido. No entanto, esse processo de nacionalização acabou não se concretizando de forma ostensiva $e$ não foi apenas por fatores políticos, tanto que mesmo após a redemocratização, os mercados de quadrinhos brasileiro e chileno continuam sendo fortemente dominados pelas publicações estrangeiras.

A não ser pelo caso excepcional da Turma da Mônica, de Mauricio de Sousa, os novos homens do amanhã, nascidos não em Krypton, mas em terras sulamericanas, ainda estão por surgir e suas vagas continuam esperando por heróis que as preencham.

\section{Referências}

BARRETO, José Geraldo. Apressado para nada. Rio de Janeiro: Garamond, 2001.

DORFMAN, Ariel; MATTELART, Armand. Para ler o Pato Donald. 2. ed. Rio de Janeiro: Paz e Terra, 1978.

MONTEALEGRE, Jorge (ed.). Apariciones $y$ desapariciones de Luiz Jiménez. Santiago de Chile: Ediciones Asterion, 2011.

RAMOS, Paulo. Bienvenido: um passeio pelos quadrinhos argentinos. Campinas: Zarabatana, 2010.

SILVA JR., Gonçalo. A guerra dos gibis. São Paulo: Companhia das Letras. 2004. 